\title{
Impact of the HEAD-US Scoring System for Observing the Protective Effect of Prophylaxis in Hemophilia Patients: A Prospective, Multicenter, Observational Study
}

\author{
Hemofili Hastalarında Profilaksinin Koruyucu Etkisinin Gözlenmesinde HEAD-US Skorlama \\ Sisteminin Önemi: Prospektif, Çok Merkezli ve Gözlemsel Bir Çalışma
}

\begin{abstract}
(D) Kaan Kavaklı1, (D) Süha Süreyya Özbek², (D) Ali Bülent Antmen³, (D) Fahri Şahin4, (D) Şevkiye Selin Aytaç5, (D) Alphan Küpesiz6,

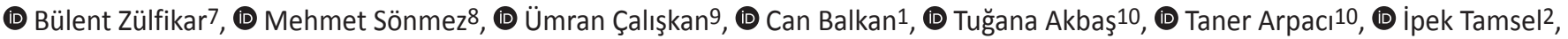
(D) Turgut Seber11, (D) Berna Oğuz11, (D) Can Çevikol12, (D) Mesut Bulakçı7, (D) Polat Koşucu13, (D) Demet Aydoğdu14, (D) ilgen Şaşmaz³, (D) Gülen Tüysüz6 ${ }^{6}$, (D) Başak Koç7 , (D) Hüseyin Tokgöz99, (D) Zuhal Mehrekula4, (D) Burcu Özkan15
\end{abstract}

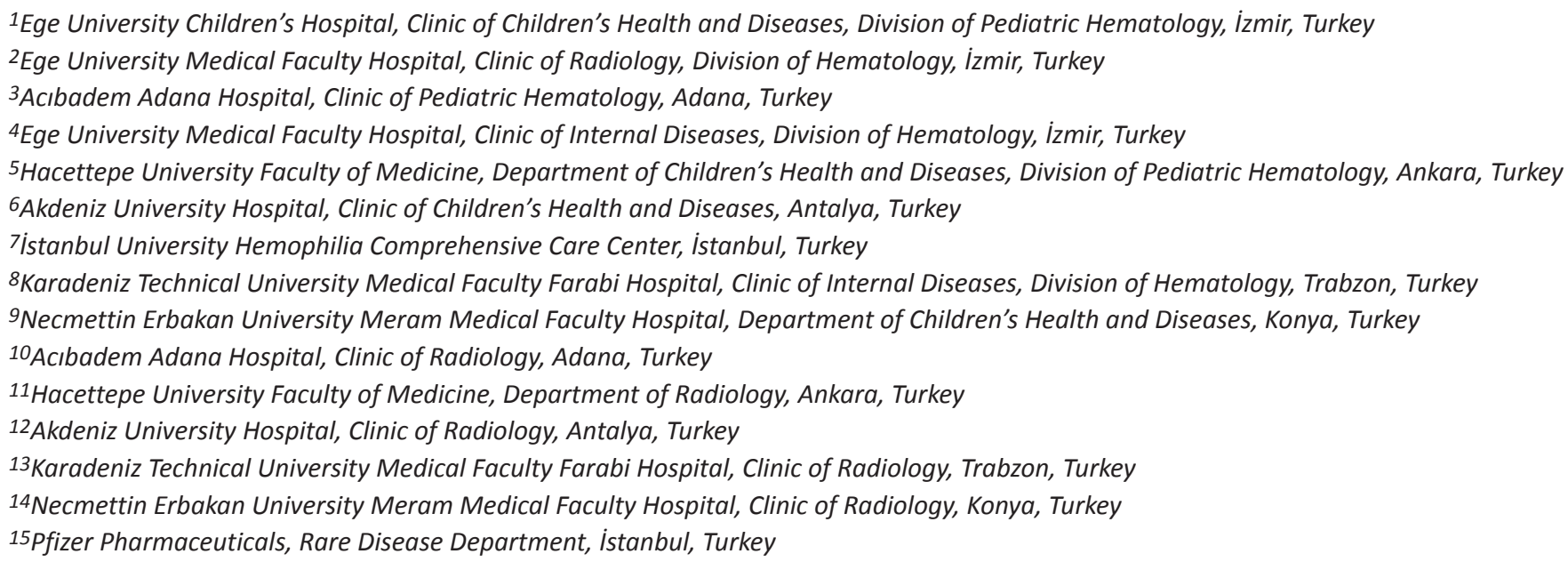

\section{Abstract}

Objective: This study aimed to observe the preventive effect of prophylactic treatment on joint health in people with hemophilia $(\mathrm{PwH})$ and to investigate the importance of integration of ultrasonographic examination into clinical and radiological evaluation of the joints.

Materials and Methods: This national, multicenter, prospective, observational study included male patients aged $\geq 6$ years with the diagnosis of moderate or severe hemophilia A or B from 8 centers across Turkey between January 2017 and March 2019. Patients were followed for 1 year with 5 visits (baseline and $3^{\text {rd }}, 6^{\text {th }}, 9^{\text {th }}$, and $12^{\text {th }}$ month visits). The Hemophilia Joint Health Score (HJHS) was used for physical examination of joints, the Pettersson scoring system was used for radiological assessment, point-of-care (POC) ultrasonography was used for bilateral examinations of joints, and the Hemophilia Early Arthropathy Detection with Ultrasound (HEAD-US) score was used for evaluation of ultrasonography results.

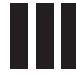

$\ddot{0} z$

Amaç: Bu çalışmada hemofili hastalarında profilaksinin eklem sağlığı üzerindeki koruyucu etkisini gözlemlemek ve eklemlerin klinik ve ultrasonografik olarak değerlendirilmesinin öneminin araştırılması amaçlandı.

Gereç ve Yöntemler: Ulusal, çok merkezli, prospektif ve gözlemsel olan araştırma 0cak 2017 - Mart 2019 arasında 8 ayrı merkezde takip edilen erkek ve 6 yaşından büyük orta seviyede veya ağır hemofili-A ve hemofili-B hastalarını kapsıyordu. Hastalar 1 yıllık takip sırasında toplam 5 ayrı vizitte (başlangıç, 3. ay, 6. ay, 9. ay ve 12. ay) değerlendirildi. Hemofili Eklem Sağlığı Skoru (HJHS) eklemlerin fiziksel bakısında kullanılırken Petterson skorlama sistemi radyolojik bakı sırasında değerlendirildi. Ayrıca, hasta başı ultrasonografisiyle bilateral eklem incelemeleri yapılarak HEAD-US skorlama yöntemiyle eklem skorları belirlendi. 
Abstract

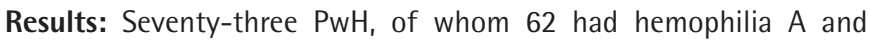
11 had hemophilia $B$, were included and $24.7 \%$ had target joints at baseline. The HJHS and HEAD-US scores were significantly increased at the $12^{\text {th }}$ month in all patients. These scores were also higher in the hemophilia A subgroup than the hemophilia B subgroup. However, in the childhood group, the increment of scores was not significant. The HEAD-US total score was significantly correlated with both the HJHS total score and Pettersson total score at baseline and at the $12^{\text {th }}$ month.

Conclusion: The HEAD-US and HJHS scoring systems are valuable tools during follow-up examinations of $\mathrm{PwH}$ and they complement each other. We suggest that POC ultrasonographic evaluation and the HEAD-US scoring system may be integrated into differential diagnosis of bleeding and long-term monitoring for joint health as a routine procedure.

Keywords: Hemophilic arthropathy, Joint Scores, HJHS, Ultrasonography $\ddot{0} \mathrm{z}$

Bulgular: Çalışmada 62'si hemofili A ve 11'I hemofili B olan 73 hastanın $\% 24,7$ 'sinde hedef eklem varlığı mevcuttu. HJHS ve HEAD-US skorlarının tüm hastalarda takibin 12. ayında anlamlı olarak arttığı gözlendi. Hemofili A hastalarında daha yüksek skorlar saptandı. Skor artımı alt gruplarda değerlendirildiğinde çocukluk yaş grubunda artışın anlamlı olmadığı gözlendi. Başlangıçta ve 12. ayda yapılan üçlü bakıda HJHS, HEAD-US ve Petterson skorlarının anlamlı olarak korele olduğu saptandı.

Sonuç: HJHS eklem skoru ile HEAD-US radyolojik skorlamasının hemofili hastalarının eklem sağlığının takibinde çok değerli olup birbirlerini destekledikleri yakından gözlendi. Hasta başı US skorlama sistemlerinin günümüzde hemofilide eklem sağlığının rutin takip ve izlemi sürecinde hem kanama ayırıcı tanısı hem de uzun dönemli takip açısından oldukça değerli bir yeri olacağını düşünüyoruz.

Anahtar Sözcükler: Hemofilik artropati, Eklem skorları, HJHS, Ultrasonografi

\section{Introduction}

The goal of hemophilia treatment is to prevent bleeding by replacement of factor concentrates or substitution of missing coagulation factors. Coagulation factors can be given for prophylaxis (primary and secondary prophylaxis, etc.) or for treatment when needed [1]. Prevention of bleeding via prophylaxis is considered the gold-standard treatment in cases of severe hemophilia $[1,2]$. Provision of early prophylaxis for severely hemophilic children can completely or largely prevent life-threatening bleeding, chronic joint diseases, and disabilities; thus, requirements for surgical interventions can be decreased and both health and social well-being of people with hemophilia $(\mathrm{PwH})$ can be improved $[1,2,3]$.

Evaluation of joint status is crucial not only for staging joint disease but also for the follow-up of prophylaxis and for evaluating outcomes of replacement therapy. Joint function is widely assessed by the Hemophilia Joint Health Score (HJHS), but implementation of the HJHS requires training and experience. The Pettersson scoring system, a radiological joint scoring system, gives quite reliable outcomes when applied by an experienced radiologist $[4,5]$. Magnetic resonance imaging (MRI) is a more sensitive imaging method than plain radiogram in evaluating the joints. Nevertheless, MRI has disadvantages such as long scanning period, high cost, limited availability, and need for sedation in young children [4,5]. However, ultrasonography may provide advantages such as appropriate cost, availability, repeatability, faster examination, no need for sedation while examining children, and scanning of multiple joints and dynamic examination of joints in a single session.

The present study aimed to observe the preventive effect of prophylactic treatment on joint health in $\mathrm{PwH}$ and to investigate the importance of integration of point of-care (POC) ultrasonographic examination into clinical and radiological evaluation of the joints.

\section{Materials and Methods}

\section{Patients}

The current study was designed as a national, multicenter, prospective, non-interventional, observational study. A total of 8 centers across Turkey were selected and the data were collected from January 2017 through March 2019. Male patients aged $\geq 6$ years with the diagnosis of moderate or severe hemophilia $A$ or hemophilia B (factor level $<2 \%$ ) were included in the study. The pediatric group (47.9\%) ranged in age from 6 to 18 years while the adult group (52.1\%) ranged in age from 19 to 70 years (Table 1).

Patients with communication difficulties (unable to understand or speak Turkish) or cognitive dysfunction and patients with inhibitors were excluded. The study was approved by the Clinical Research Ethics Committee of the Ege University Faculty of Medicine and written informed consent was obtained from the patients or their legal representatives.

\section{Procedure}

After enrollment in the study, the patients were followed for 12 months with a total of 5 visits (baseline and $3^{\text {rd }}, 6^{\text {th }}, 9^{\text {th }}$, and $12^{\text {th }}$ months). In the study centers, patient data concerning demographic features and hemophilia history were recorded on case report forms at the baseline visit. Physical examinations of elbow, knee, and ankle joints were performed with the HJHS during each visit. Annual bleeding rate (ABR) was recorded every 3 months during clinical visits. 
Additionally, ultrasonographic examinations of the bilateral elbow, ankle, and knee joints were performed during each visit. Ultrasonography results of the patients were evaluated with the Hemophilia Early Arthropathy Detection with Ultrasound (HEAD-US) scoring system. Evaluations were performed by expert physiotherapists and radiologists. The same experts in each center performed the evaluations at different time points to prevent variability.

For all patients, quality of life (0oL) questionnaires were administered at the baseline, $6^{\text {th }}$ month, and $12^{\text {th }}$ month visits.

Compliance of prophylaxis and bleeding episodes were recorded every 3 months in clinical visits.

\section{Measurements}

The HJHS is a scoring system used to assess physical joint damage in $\mathrm{PwH}$ and recommended for routine follow-up assessments of joint health. Using the HJHS, the six most commonly involved joints (elbows, knees, and ankles) are evaluated in $\mathrm{PwH}$ and total scores are within the range of 0-124. High scores indicate damage/impairment [6].

The Pettersson scoring system allows detailed evaluation of radiological changes in the joints. Posterior-anterior and lateral $X$-ray images of the joints are evaluated. Scores range from 0 to 13 for a single joint and the maximum possible total score is 78 when 6 joints are evaluated $[7,8]$.

\section{Table 1. Demographics of 73 patients receiving prophylaxis.}

\begin{tabular}{|c|c|c|c|}
\hline Group & Children & Adults & All \\
\hline Patients, n & 35 & 38 & 73 \\
\hline$(\%)$ & $(47.9 \%)$ & $(52.1 \%)$ & $(100 \%)$ \\
\hline Range & $6-17$ & $18-70$ & $6-70$ \\
\hline Median & 14 & 36 & 18 \\
\hline \multicolumn{4}{|l|}{ Body mass index } \\
\hline Range & $13.2-24.8$ & $24.1-35.2$ & $13.2-35.2$ \\
\hline Median & 15.9 & 28.6 & 23.8 \\
\hline Mean \pm SD & $16.1 \pm 5.6$ & $25.6 \pm 14.2$ & $23.4 \pm 5.2$ \\
\hline Range & $6-70$ & $12-60$ & \\
\hline Median & 17.5 & 19.0 & \\
\hline Mean \pm SD & $21.3 \pm 14.1$ & $26.5 \pm 16.7$ & \\
\hline \multicolumn{4}{|l|}{ Severity } \\
\hline Severe & 68 & 58 & 10 \\
\hline Moderate & 5 & 4 & 1 \\
\hline${ }^{*}$ Presence of target joint & $18(24.3 \%)$ & 15 & 3 \\
\hline *Orthopedic operation history & $23(31.5 \%)$ & 20 & 3 \\
\hline Elbow-left & 14 & 12 & 2 \\
\hline Ankle-right & 20 & 17 & 3 \\
\hline Ankle-left & 14 & 13 & 1 \\
\hline
\end{tabular}


The HEAD-US scoring system was developed by Martinoli et al. [9]. It is based on three markers for the three main sets of joints (knees, elbows, and ankles): synovitis (score of 0-2), cartilage (score of $0-4)$, and subchondral bone (score of $0-2$ ), with a maximum score of 8 points per joints.

The Short Form-36 (SF-36) is a questionnaire widely used to assess health-related QoL. Based on the scores of 8 dimensions of health (physical functioning, bodily pain, role limitations due to physical health problems, role limitations due to personal or emotional problems, general mental health, social functioning, energy/fatigue or vitality, and general health perceptions), two component summaries (physical component summary and mental component summary) are obtained. Higher scores indicate better health status [10].

The Euro0ol-5 Dimension (EQ-5D) is another questionnaire frequently used to assess health-related OoL. Five parameters of health (mobility, self-care, usual activities, pain/discomfort, and anxiety/depression) are evaluated. Higher scores indicate better OoL [11]. In the present study, the three-level version (EQ-5D-3L) was used.

Patients receiving prophylaxis were evaluated using scoring systems and QoL parameters. Prospective evaluations of patients were provided for the one-year observational period.

Bleeding frequency and target joint availability are main reasons for starting prophylaxis for patients with moderate hemophilia. They were mostly receiving secondary prophylaxis.

Children below 10 years of age were in the primary prophylaxis group, whereas older children (10-18 years) received secondary prophylaxis. Most of the adult group received secondary or tertiary prophylaxis. Primary prophylaxis was started at once weekly and then increased to twice and thrice weekly. Most secondary prophylaxis patients received infusions twice or thrice weekly.

\section{Sample Size}

The sample size was calculated as $80 \mathrm{PwH}$ with the assumptions of the rate of damaged joints being $8 \%$ in $\mathrm{PwH}$ receiving prophylactic treatment and the rate of damaged joints being 25\% in $\mathrm{PwH}$ not receiving prophylactic treatment, with 80\% power when the statistical significance level was presumed as 0.05 .

\section{Statistical Analysis}

Data analysis was performed using PASW Statistics for Windows, Version 18.0 (SPSS Inc., Chicago, IL, USA). For descriptive statistics, numerical variables were expressed as mean, standard deviation, median, and minimum-maximum and categorical variables were expressed as number and percentage. Student's t-test was performed in comparisons of ultrasonography scores and OoL scores at each visit when the condition of normal distribution was fulfilled. The Mann-Whitney $U$ test was used when the condition of normal distribution was not fulfilled. For normally distributed data, repeated measures analysis was performed for the comparison of change in ultrasonography scores and OoL scores with time in the groups. When the normal distribution condition was not fulfilled, the Friedman test was performed separately in the groups. Spearman's rho correlation test was used for correlation analysis.

The statistical significance level was set at $p<0.05$.

\section{Results}

The present study included 78 male hemophilic patients, of whom 73 received prophylactic treatment and 5 received on-demand treatment in case of bleeding. The 73 patients receiving prophylaxis were included in the analyses. Of those patients, 62 had hemophilia A (58 severe and 4 moderate) and 11 had hemophilia B (10 severe and 1 moderate). General characteristics of the patients and disease-related data are presented in Table 1.

Among the included patients, $24.7 \%$ had target joints at baseline. The most commonly affected joint was the right ankle (27.4\%). Overall, 31.5\% of the included patients underwent major or minor surgical procedures and radioactive synovectomy was performed for only 6 patients. More than half of the patients were not able to go to work because of hemophilia in the last 3 months (Table 1).

The ABRs for all patients, for children, and for adults are shown in Table 2. The elevation of ABR rates was not significant for children or for adults.

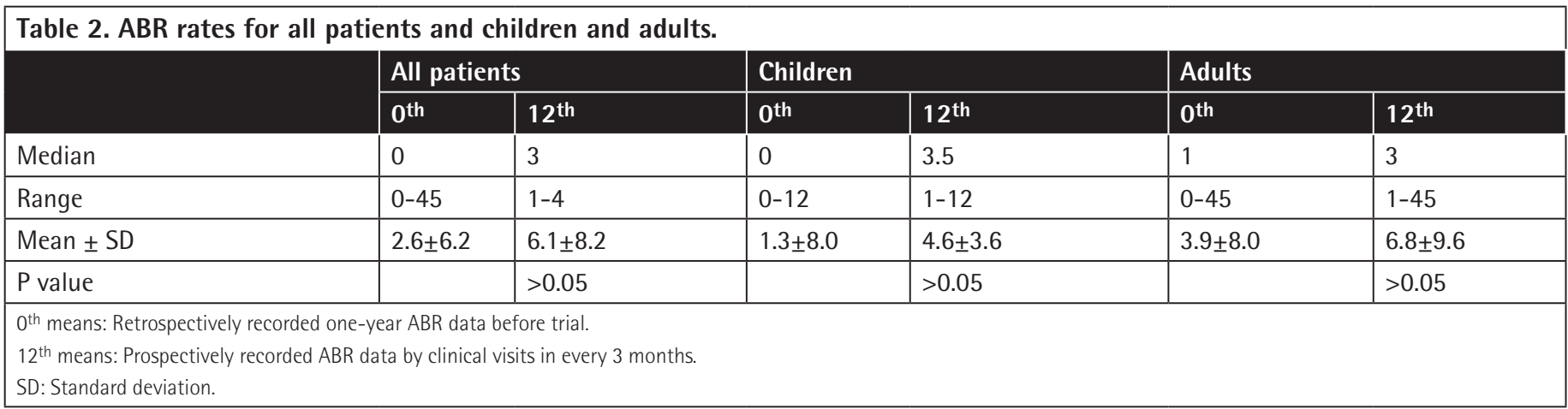


Moreover, joint scores of all patients at the baseline and follow-up visits are shown in Tables 3-6. When the scores at the baseline and $12^{\text {th }}$ month were compared, there were significant increases in both the HJHS and HEAD-US scores at the $12^{\text {th }}$ month in all patients. Separating the patients by age, no significant increase in any of the scores was observed in children, but significant increases in the HJHS, HEAD-US, and Pettersson scores were seen in the adult group.

Evaluation of the patients in terms of hemophilia $A$ and hemophilia B subgroups showed significant increases in the HJHS and HEAD-US scores at the $12^{\text {th }}$ month in the hemophilia A subgroup (Tables 3 and 6). However, the number of hemophilia B patients included in this study is much smaller in comparison to the hemophilia A subgroup. For subgroup analysis by prophylaxis groups, results are shown in Tables 4 and 5. The elevated scores found in the adult group were statistically significant compared to the children.
Correlation analyses were performed for the joint scores at the baseline and 12th month. Among all patients, the HJHS total score was found to significantly correlate with the HEAD-US total score at the baseline and $12^{\text {th }}$ month. Moreover, there was a significant correlation between the Pettersson total score and the HEAD-US total score at baseline and the $12^{\text {th }}$ month (Table 7). Strong correlation was found among the three scoring systems (HJHS, HEAD-US, and Pettersson) at baseline and after 12 months of observation $(p<0.001)$.

There were no significant differences in the QoL scores between the baseline and $12^{\text {th }}$ month in all patients.

Neither pediatric vs. adult group nor hemophilia A vs. hemophilia B comparisons were significant.

Comparisons of the QoL scores of the patients between the baseline and $12^{\text {th }}$ month are presented in Table 8 .

\begin{tabular}{|c|c|c|c|c|c|c|}
\hline & & $\begin{array}{l}\text { HJHS } \\
\text { Total score }\end{array}$ & & $\begin{array}{l}\text { HEAD-US } \\
\text { Total score }\end{array}$ & & $\begin{array}{l}\text { Pettersson } \\
\text { Total score }\end{array}$ \\
\hline & $\mathbf{n}$ & $\begin{array}{l}\text { Mean } \pm \text { SD } \\
\text { Median (min-max) }\end{array}$ & n & $\begin{array}{l}\text { Mean } \pm \text { SD } \\
\text { Median (min-max) }\end{array}$ & $n$ & $\begin{array}{l}\text { Mean } \pm \text { SD } \\
\text { Median }(\min -\max )\end{array}$ \\
\hline Baseline & 60 & $\begin{array}{l}9.97 \pm 12.41 \\
3(0-48) \\
\end{array}$ & 61 & $\begin{array}{l}9.70 \pm 9.25 \\
7(0-33) \\
\end{array}$ & 15 & $\begin{array}{l}15.4 \pm 15.71 \\
11(0-47) \\
\end{array}$ \\
\hline $3^{\text {rd }}$ month & 58 & $\begin{array}{l}11.1 \pm 13.42 \\
5.5(0-55)\end{array}$ & 56 & $\begin{array}{l}9.75 \pm 9.87 \\
7(0-36) \\
\end{array}$ & - & - \\
\hline $6^{\text {th }}$ month & 58 & $\begin{array}{l}13.95 \pm 16.92 \\
5(0-56)\end{array}$ & 50 & $\begin{array}{l}9.48 \pm 10.41 \\
6.5(0-40) \\
\end{array}$ & - & - \\
\hline $9^{\text {th }}$ month & 53 & $\begin{array}{l}9.79 \pm 13.4 \\
3(0-50)\end{array}$ & 41 & $\begin{array}{l}9.73 \pm 10.31 \\
6(0-40)\end{array}$ & - & - \\
\hline $12^{\text {th }}$ month & 56 & $\begin{array}{l}11.18 \pm 14.55 \\
3(0-57)\end{array}$ & 53 & $\begin{array}{l}11.51 \pm 10.61 \\
8(0-40)\end{array}$ & 13 & $\begin{array}{l}17.23 \pm 17.14 \\
14(0-48)\end{array}$ \\
\hline
\end{tabular}

\begin{tabular}{|c|c|c|c|c|c|c|c|c|c|c|}
\hline & \multicolumn{5}{|c|}{$\begin{array}{l}\text { HJHS } \\
\text { Total score } \\
\text { Mean } \pm \text { SD } \\
\text { Median (min-max) }\end{array}$} & \multicolumn{5}{|c|}{$\begin{array}{l}\text { HEAD-US } \\
\text { Total score } \\
\text { Mean } \pm \text { SD } \\
\text { Median (min-max) }\end{array}$} \\
\hline & $\mathbf{n}$ & $\begin{array}{l}\text { Receiving } \\
\text { prophylaxis } \\
\text { 1-2 times a week }\end{array}$ & n & $\begin{array}{l}\text { Receiving } \\
\text { prophylaxis } \\
\geq 3 \text { times a week }\end{array}$ & $\mathbf{P}$ & n & $\begin{array}{l}\text { Receiving } \\
\text { prophylaxis } \\
\text { 1-2 times a week }\end{array}$ & $\mathbf{n}$ & $\begin{array}{l}\text { Receiving } \\
\text { prophylaxis } \\
\geq 3 \text { times a week }\end{array}$ & p \\
\hline Baseline & 35 & $\begin{array}{l}11.74 \pm 13.32 \\
8(0-48)\end{array}$ & 15 & $\begin{array}{l}5.87 \pm 9 \\
2(0-29)\end{array}$ & 0.517 & 39 & $\begin{array}{l}10.05 \pm 10.05 \\
7(0-33)\end{array}$ & 13 & $\begin{array}{l}6.69 \pm 6.17 \\
5(0-20)\end{array}$ & 0.172 \\
\hline $\begin{array}{l}3^{\text {rd }} \\
\text { month }\end{array}$ & 34 & $\begin{array}{l}12.06 \pm 13.22 \\
6.5(0-48)\end{array}$ & 16 & $\begin{array}{l}5.75 \pm 6.81 \\
3(0-25)\end{array}$ & 0.973 & 31 & $\begin{array}{l}10.61 \pm 11.45 \\
7(0-36)\end{array}$ & 16 & $\begin{array}{l}8.19 \pm 6.96 \\
7(0-22) \\
\end{array}$ & 0.244 \\
\hline $\begin{array}{l}6^{\text {th }} \\
\text { month }\end{array}$ & 29 & $\begin{array}{l}12.14 \pm 14.55 \\
4(0-48)\end{array}$ & 18 & $\begin{array}{l}11.94 \pm 15.52 \\
5.5(0-54)\end{array}$ & 0.410 & 28 & $\begin{array}{l}9.46 \pm 12 \\
4(0-40)\end{array}$ & 13 & $\begin{array}{l}8.38 \pm 6.05 \\
9(0-23)\end{array}$ & 0.895 \\
\hline $\begin{array}{l}9^{\text {th }} \\
\text { month }\end{array}$ & 28 & $\begin{array}{l}8.46 \pm 12.59 \\
3(0-48)\end{array}$ & 16 & $\begin{array}{l}10.13 \pm 12.09 \\
6(0-38)\end{array}$ & 0.739 & 23 & $\begin{array}{l}9.87 \pm 11.25 \\
6(0-40)\end{array}$ & 11 & $\begin{array}{l}8.27 \pm 5.9 \\
8(0-22)\end{array}$ & 0.366 \\
\hline $\begin{array}{l}12^{\text {th }} \\
\text { month }\end{array}$ & 31 & $\begin{array}{l}10.48 \pm 13.44 \\
3(0-48)\end{array}$ & 14 & $\begin{array}{l}10.79 \pm 13.41 \\
5(0-41)\end{array}$ & 0.557 & 32 & $\begin{array}{l}11.44 \pm 11.83 \\
7(0-40)\end{array}$ & 11 & $\begin{array}{l}10.45 \pm 6.19 \\
10(0-22)\end{array}$ & 0.795 \\
\hline
\end{tabular}




\section{Discussion}

In all patients, there were significant increases in the HEADUS and HJHS scores during the one-year follow-up period despite prophylaxis. This was consistent with the results obtained from the study by Warren et al. [12], in which only a small number of PwH had no damage in their joints when they reached adolescence, in spite of early prophylaxis. In the present study, subgroup evaluation according to age revealed a significant increase in the joint scores from baseline to the $12^{\text {th }}$ month in the adult group but not in the pediatric group. In other words, prophylactic treatment slowed down the progression upon onset of arthropathy in children, but degenerative arthropathic changes persisted in adult patients. Subgroup analysis results supported the importance of early prophylaxis in childhood.

Similarly, Warren et al. [12] reported that the risks of osteochondral damage on $\mathrm{MRI}$ and increased $A B R$ and joint $A B R$ were significantly higher in the children who began using prophylactic factor VIII after 6 years of age compared to children for whom prophylaxis was initiated before 2.5 years of age. These results show the importance of preventing initiation of joint damage by means of prophylaxis at an early stage in life, because the earlier the damage occurs, the more difficult it is to prevent its progression. For this reason, examination of the joints by means of regular follow-up is important for early detection and prevention of arthropathic changes in PwH. Geraghty et al. [13] showed that nonadherence to treatment was higher among adults compared to children with hemophilia. As adolescent and adult patients are prone to failures to adhere to clinical practice, we used reminders about compliance every 3 months during clinical visits.

Early initiation of prophylactic treatment and good adherence to treatment are important factors to reduce the incidence of bleeding and to preserve joint functions in PwH $[14,15]$.

Hemophilic arthropathy is a progressive condition and negatively impacts the QoL of patients as damage progresses. It has been reported that QoL is lower in PwH as compared to the general population [16]. Earlier studies have demonstrated poorer OoL in patients with severe joint problems $[16,17,18]$. These data support the importance of appropriate treatment to limit joint injury. In the present study, QoL was assessed using the

\begin{tabular}{|c|c|c|c|c|}
\hline \multirow[b]{2}{*}{ Total scores } & \multicolumn{2}{|c|}{ Baseline } & \multirow{2}{*}{\begin{tabular}{|l|}
$12^{\text {th }}$ month \\
Mean \pm SD \\
Median (min-max)
\end{tabular}} & \multirow[b]{2}{*}{ P } \\
\hline & $\mathbf{n}$ & $\begin{array}{l}\text { Mean } \pm \text { SD } \\
\text { Median (min-max) }\end{array}$ & & \\
\hline \multicolumn{5}{|l|}{ Children (6-17 years) } \\
\hline HJHS & 29 & $\begin{array}{l}1.86 \pm 3.07 \\
1(0-13)\end{array}$ & $\begin{array}{l}3.17 \pm 7.07 \\
1(0-36)\end{array}$ & 0.166 \\
\hline$<3$ years of age & 17 & $\begin{array}{l}1.41 \pm 2.67 \\
0(0-11)\end{array}$ & $\begin{array}{l}3.24 \pm 8.55 \\
1(0-36)\end{array}$ & 0.158 \\
\hline$\geq 3$ years of age & 10 & $\begin{array}{l}2.7 \pm 3.86 \\
2(0-13)\end{array}$ & $\begin{array}{l}3.6 \pm 4.86 \\
2(0-16)\end{array}$ & 0.438 \\
\hline HEAD-US & 29 & $\begin{array}{l}4.03 \pm 4.59 \\
2(0-16)\end{array}$ & $\begin{array}{l}4.69 \pm 4.35 \\
5(0-14)\end{array}$ & 0.322 \\
\hline$<3$ years of age & 17 & $\begin{array}{l}4.53 \pm 5.57 \\
1(0-16)\end{array}$ & $\begin{array}{l}4.94 \pm 4.6 \\
5(0-14)\end{array}$ & 0.623 \\
\hline$\geq 3$ years of age & 9 & \begin{tabular}{|l|}
$3.44 \pm 2.96$ \\
$3(0-9)$
\end{tabular} & $\begin{array}{l}4.67 \pm 4.58 \\
5(0-11)\end{array}$ & 0.395 \\
\hline \multicolumn{5}{|l|}{ Adults ( $\geq 18$ years) } \\
\hline HJHS & 23 & $\begin{array}{l}17.96 \pm 12.55 \\
17(0-48)\end{array}$ & $\begin{array}{l}22.43 \pm 15.4 \\
22(0-57)\end{array}$ & 0.017 \\
\hline Receiving $<10$ years of treatment & 3 & $\begin{array}{l}21.33 \pm 4.51 \\
21(17-26)\end{array}$ & $\begin{array}{l}23.67 \pm 2.08 \\
23(22-26)\end{array}$ & - \\
\hline Receiving $\geq 10$ years of treatment & 20 & $\begin{array}{l}17.45 \pm 13.35 \\
13.5(0-48)\end{array}$ & $\begin{array}{l}22.25 \pm 16.55 \\
20(0-57)\end{array}$ & 0.031 \\
\hline HEAD-US & 23 & $\begin{array}{l}17.3 \pm 8.96 \\
18(0-33)\end{array}$ & $\begin{array}{l}19.78 \pm 10.34 \\
22(0-40)\end{array}$ & 0.006 \\
\hline Receiving $<10$ years of treatment & 4 & $\begin{array}{l}21.25 \pm 6.29 \\
22(14-27)\end{array}$ & $\begin{array}{l}26 \pm 4.08 \\
24.5(23-32)\end{array}$ & - \\
\hline Receiving $\geq 10$ years of treatment & 19 & $\begin{array}{l}16.47 \pm 9.35 \\
17(0-33)\end{array}$ & $\begin{array}{l}18.47 \pm 10.83 \\
19(0-40)\end{array}$ & 0.023 \\
\hline
\end{tabular}


EQ-5D-3L and SF-36 questionnaires. The OoL scores of the patients were generally high, indicating a better $\mathrm{OoL}$, and the mean scores were similar at the baseline and $12^{\text {th }}$ month. Assessment of QoL not only gives information about clinical statuses of patients but also provides an objective criterion for measuring benefit gained from treatment $[19,20]$. Better adherence of patients to treatment is associated with better outcomes and is a factor that improves $\operatorname{CoL}[21,22,23]$.

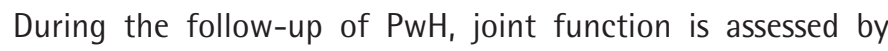
physical examination and the HJHS is widely used for scoring. However, implementation of the HJHS requires training and experience [24]. Plain radiographs have also long been used to evaluate the musculoskeletal system. The Pettersson scoring system, a radiological joint scoring system, gives quite reliable outcomes when applied by an experienced radiologist [24]. $\mathrm{MRI}$ is a more sensitive imaging method than plain radiogram

\begin{tabular}{|c|c|c|c|c|}
\hline \multirow[b]{2}{*}{ Total scores } & \multicolumn{2}{|c|}{ Baseline } & \multirow{2}{*}{\begin{tabular}{|l|}
$12^{\text {th }}$ month \\
Mean \pm SD \\
Median (min-max)
\end{tabular}} & \multirow[b]{2}{*}{$p$} \\
\hline & $n$ & $\begin{array}{l}\text { Mean } \pm \text { SD } \\
\text { Median (min-max) }\end{array}$ & & \\
\hline \multicolumn{5}{|l|}{ All patients } \\
\hline HJHS & 52 & $\begin{array}{l}8.98 \pm 11.76 \\
3(0-48)\end{array}$ & $\begin{array}{l}11.69 \pm 14.93 \\
3(0-57)\end{array}$ & 0.007 \\
\hline HEAD-US & 52 & $\begin{array}{l}9.90 \pm 9.51 \\
7(0-33)\end{array}$ & $\begin{array}{l}11.37 \pm 10.67 \\
8(0-40)\end{array}$ & 0.007 \\
\hline Pettersson & 13 & $\begin{array}{l}17.00 \pm 16.32 \\
12(0-47)\end{array}$ & \begin{tabular}{|l}
$17.23 \pm 17.14$ \\
$14(0-48)$
\end{tabular} & 0.631 \\
\hline \multicolumn{5}{|c|}{ Children (6-17 years) } \\
\hline HJHS & 29 & $\begin{array}{l}1.86 \pm 3.07 \\
1(0-13)\end{array}$ & $\begin{array}{l}3.17 \pm 7.07 \\
1(0-36)\end{array}$ & 0.166 \\
\hline HEAD-US & 29 & $\begin{array}{l}4.03 \pm 4.59 \\
2(0-16)\end{array}$ & $\begin{array}{l}4.69 \pm 4.35 \\
5(0-14)\end{array}$ & 0.322 \\
\hline Pettersson & 6 & $\begin{array}{l}3.83 \pm 4.45 \\
2.5(0-11)\end{array}$ & $\begin{array}{l}2.67 \pm 2.66 \\
2.5(0-7)\end{array}$ & 0.197 \\
\hline \multicolumn{5}{|c|}{ Adults ( $\geq 18$ years) } \\
\hline HJHS & 23 & \begin{tabular}{|l|}
$17.96 \pm 12.55$ \\
$17(0-48)$
\end{tabular} & $\begin{array}{l}22.43 \pm 15.4 \\
22(0-57)\end{array}$ & 0.017 \\
\hline HEAD-US & 23 & $\begin{array}{l}17.3 \pm 8.96 \\
18(0-33)\end{array}$ & $\begin{array}{l}19.78 \pm 10.34 \\
22(0-40)\end{array}$ & 0.006 \\
\hline Pettersson & 7 & $\begin{array}{l}28.29 \pm 13.94 \\
32(12-47)\end{array}$ & $\begin{array}{l}29.71 \pm 13.7 \\
32(14-48)\end{array}$ & 0.041 \\
\hline \multicolumn{5}{|c|}{ Hemophilia A patients } \\
\hline HJHS & 42 & \begin{tabular}{|l}
$8.76 \pm 11.56$ \\
$2.5(0-48)$
\end{tabular} & $\begin{array}{l}10.95 \pm 13.61 \\
3(0-48)\end{array}$ & 0.020 \\
\hline HEAD-US & 43 & $\begin{array}{l}9.35 \pm 9.63 \\
6(0-33)\end{array}$ & \begin{tabular}{|l}
$10.86 \pm 10.58$ \\
$7(0-40)$
\end{tabular} & 0.010 \\
\hline Pettersson & 10 & $\begin{array}{l}18.9 \pm 17.91 \\
11.5(0-47)\end{array}$ & $\begin{array}{l}18.7 \pm 18.99 \\
10.5(0-48)\end{array}$ & 0.752 \\
\hline \multicolumn{5}{|c|}{ Hemophilia B patients } \\
\hline HJHS & 10 & $\begin{array}{l}9.9 \pm 13.16 \\
3.5(0-36)\end{array}$ & $\begin{array}{l}14.8 \pm 20.15 \\
5(0-57)\end{array}$ & 0.232 \\
\hline HEAD-US & 9 & $\begin{array}{l}12.56 \pm 8.99 \\
13(1-30)\end{array}$ & $\begin{array}{l}13.78 \pm 11.4 \\
11(0-33)\end{array}$ & 0.338 \\
\hline Pettersson & 3 & \begin{tabular}{|l}
$10.67 \pm 8.74$ \\
$13(1-18)$
\end{tabular} & $\begin{array}{l}12.33 \pm 9.61 \\
14(2-21)\end{array}$ & 0.102 \\
\hline
\end{tabular}


in evaluating the joints. Nevertheless, MRI has practical disadvantages such as the long scanning period, high cost, limited availability, and need for sedation in young children [24]. There is a need for an easy, cost-effective, repeatable, efficient, and reliable joint scoring system. Therefore, ultrasonography has become an attractive method in the last years for objective evaluation of joint status and for early detection of changes during periodic follow-up $[25,26,27,28,29]$. Ultrasonography provides advantages such as appropriate cost, availability, repeatability, faster examination, no need for sedation while examining children, and scanning of multiple joints and dynamic examination of joints in a single session [30]. Ultrasonography

\begin{tabular}{|c|c|c|c|c|c|c|}
\hline & \multicolumn{3}{|c|}{ Baseline } & \multicolumn{3}{|c|}{$12^{\text {th }}$ month } \\
\hline & $n$ & RHO & p & $\mathbf{n}$ & RHO & p \\
\hline HEAD-US & 14 & 0.842 & $<0.001$ & 13 & 0.861 & $<0.001$ \\
\hline HJHS & 14 & 0.828 & $<0.001$ & 13 & 0.827 & $<0.001$ \\
\hline \multicolumn{7}{|c|}{$\begin{array}{l}\text { *Spearsman's rho correlation test. } \\
\text { HJHS: Hemophilia Joint Health Score; HEAD-US: Hemophilia Early Arthropathy } \\
\text { Detection with Ultrasound. }\end{array}$} \\
\hline
\end{tabular}

allows detection and quantitation of signs of disease activity (fluid collection in the joint, synovial hypertrophy, etc.) and degenerative cases (osteochondral changes, etc.) and it is also beneficial in discriminating inflammatory (serous) effusion from hemarthrosis. Ultrasonography, as a simple and practical tool, is a powerful potential tool to be utilized in routine hemophilia care in the near future [28].

Several scoring systems have recently been proposed to provide objectivity in ultrasonographic evaluation; the HEAD-US is one of them [28]. The HEAD-US scoring system has advantages such that it can be applied by non-imaging specialists. However, even though this scoring system can be performed by non-radiologists after a short training period, the speed of the exam is dependent on the sonographer's experience level $[24,31]$.

There are studies using the HEAD-US scoring to assess joint status in $\mathrm{PwH}$ and evaluating its correlation with HJHS scores. In a study evaluating joint status in children with severe hemophilia A receiving prophylaxis, $85.3 \%$ of the joints were found normal by the HJHS, whereas $79.0 \%$ of the joints were found normal by the HEAD-US scoring system [32]. While there

\section{Table 8. Comparison of the quality of life scores of the patients between the baseline and $12^{\text {th }}$ month.}

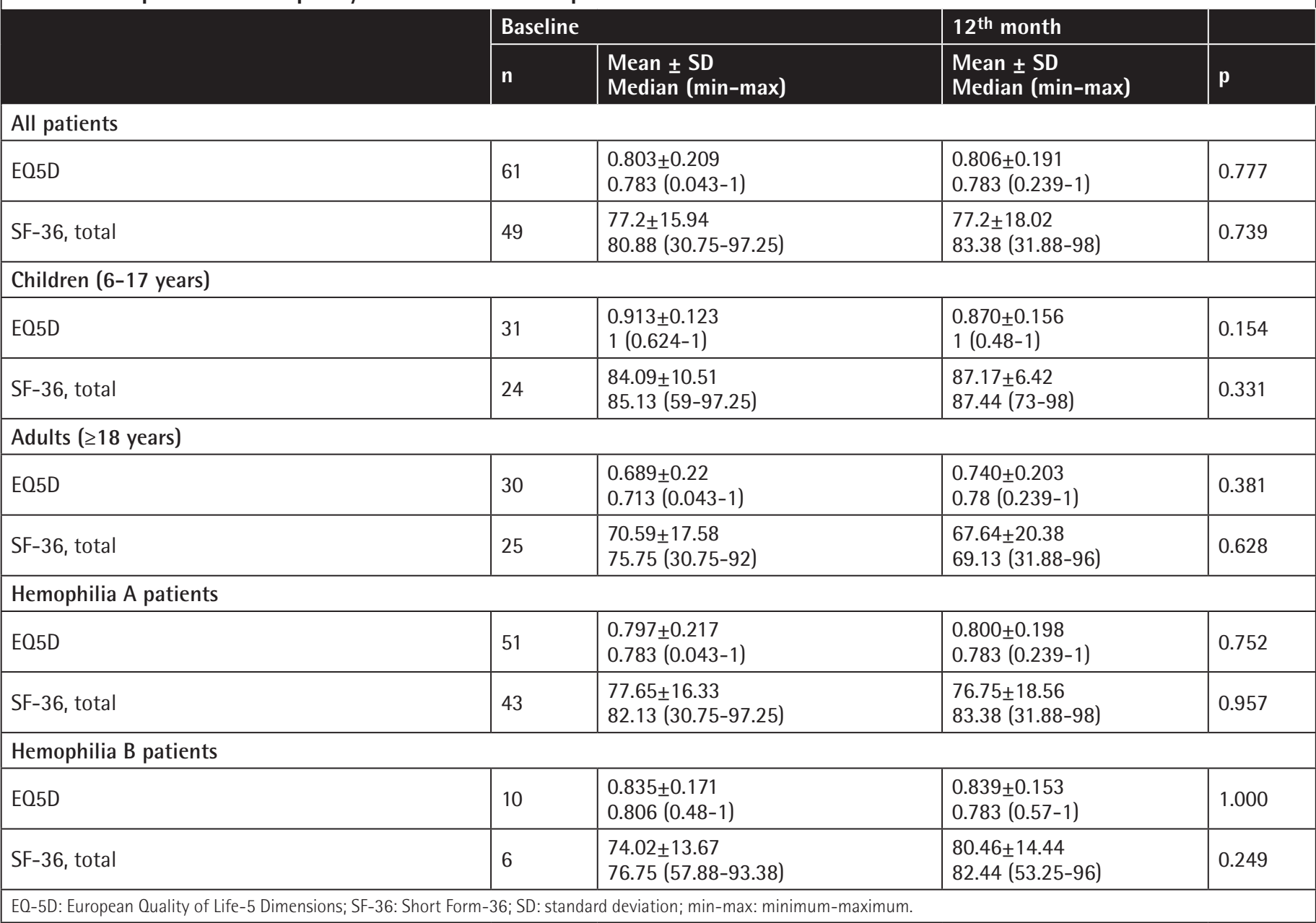


was a correlation between the HEAD-US scores and bleeding scores, no correlation was determined between the HEAD-US and HJHS scores. Nevertheless, the HJHS and HEAD-US scores were concordant for $73.4 \%$ of the joints. Ultrasound detected minimal changes in $19.6 \%$ of the joints with normal physical functioning, whereas $12.2 \%$ of the joints that were considered normal on ultrasound showed changes according to the HJHS. As a consequence, ultrasound detected a higher percentage of abnormalities than physical examination [32]. Jiménez-Yuste et al. [33] carried out a study of hemophilia B patients and concluded that using the HEAD-US scoring system in routine practice provided patients with better and more objective evaluation and contributed to personalization of treatment. Li et al. [34] determined a significant correlation between the HEAD-US and HJHS scores in PwH receiving prophylactic treatment. Banchev et al. [35] reported a strong correlation between three-year joint bleeding rates and HEAD-US total scores for ankle and knee joints in hemophilia A patients receiving secondary/tertiary prophylaxis. Plut et al. [36] conducted a study of patients with severe hemophilia and determined a very high correlation between the overall HEAD-US scores and overall International Prophylaxis Study Group MRI scores. They suggested the HEAD-US protocol as a fast, reliable, and accurate method for detecting hemophilic arthropathy and determining its degree. In the present study, considering all patients, the HEAD-US total scores showed a correlation with both the HJHS total score and the Pettersson total score. Joint tissue activity and damage examination (the JADE protocol) was developed for soft tissue and osteochondral measurements for a POC ultrasound scoring system in the United States, patented by the University of California-San Diego [37]. The JADE protocol has similar principles, is easy to learn and administer, and is ideal for use in routine practice as well as achieving useful outcomes as a research tool. Both protocols (JADE and HEAD-US) appear feasible for quantifying hemophilic intraarticular abnormalities with lower variabilities.

\section{Study Limitations}

The main limitation of the present study was not including more patients receiving on-demand treatment and thereby not comparing the data of patients receiving prophylactic treatment with those receiving on-demand treatment. Another limitation was missing some patients during the prospective evaluation due to data deficiencies. Even though we were able to calculate statistical analysis, without any missing patients we would have been able to provide even better results.

\section{Conclusion}

The HEAD-US and HJHS scoring systems are valuable tools during follow-up examinations of patients and they complement each other. We suggest that POC ultrasonographic evaluation and the HEAD-US scoring system may be integrated into differential diagnosis not only for bleeding and but also for long-term monitoring of joint health of $\mathrm{PwH}$ as a routine procedure. It would thereby be possible to provide $\mathrm{PwH}$ maximum benefit by means of early diagnosis of joint changes and bleedings that might be overlooked during physical examination and, in turn, to personalize prophylactic treatment.

\section{Ethics}

Ethics Committee Approval: Ege University Faculty of Medicine Clinical Research Ethics Committee (date: 15.5.2016/no: 165.1/47).

\section{Informed Consent: Obtained.}

\section{Authorship Contributions}

Design: K.K.; Data Collection or Processing: K.K., S.S.Ö., A.B.A., F.Ş., S..S.A., A.K., B.Z., M.S., Ü.Ç., C.B., T.A., T.Ar., I.T., T.S., B.O., C.Ç., M.B., P.K., D.A., I.Ş., G.T., B.K., H.T., Z.M., B.Ö.; Analysis or Interpretation: K.K.

Conflict of Interest: No conflict of interest was declared by the authors.

Financial Disclosure: K. Kavaklı reports scientific advisory board and funding research from Pfizer, Bayer, Novo Nordisk, Roche, and Takeda. F. Şahin reports advisory board and funding research from Pfizer, Takeda, Bayer, and Novo Nordisk. B. Zülfikar reports advisory board and/or consultancy funding from Pfizer, Shire, Novo Nordisk, Roche, Sobi, Bayer, and Biomarin. C. Balkan reports advisory board and funding research from Pfizer, Takeda, Bayer, Novo Nordisk, and Roche. B. Özkan is an employee of Pfizer Pharmaceuticals. The remaining authors state that they had no interests that might be perceived as posing a conflict or bias.

\section{References}

1. Colvin BT, Astermark J, Fischer K, Gringeri A, Lassila R, Schramm W, Thomas A, Ingerslev J; Inter Disciplinary Working Group. European principles of haemophilia care. Haemophilia 2008;14:361-374.

2. Fischer $\mathrm{K}$, Ljung R. Primary prophylaxis in haemophilia care: Guideline update 2016. Blood Cells Mol Dis 2017;67:81-85.

3. Weyand AC, Pipe SW. New therapies for hemophilia. Blood 2019;133:389398.

4. Soliman $M$, Daruge $P$, Dertkigil SSJ, De Avila Fernandes $E$, Negrao JR, de Aguiar Vilela Mitraud S, Sakuma ETI, Fernandes ARC, Zhang N, Huo A, Li YJ, Zhou F, Rodrigues BM, Mohanta A, Blanchette VS, Doria AS. Imaging of haemophilic arthropathy in growing joints: pitfalls in ultrasound and MRI. Haemophilia 2017;23:660-672.

5. Foppen W, van der Schaaf IC, Beek FJA, Mali WPTM, Fischer K. Diagnostic accuracy of point-of-care ultrasound for evaluation of early blood-induced joint changes: Comparison with MRI. Haemophilia 2018;24:971-979.

6. Feldman BM, Funk SM, Bergstrom BM, Zourikian N, Hilliard $P$, van der Net J, Engelbert R, Petrini P, van den Berg HM, Manco-Johnson MJ, Rivard GE, Abad A, Blanchette VS. Validation of a new pediatric joint scoring system from the International Hemophilia Prophylaxis Study Group: validity of the 
hemophilia joint health score. Arthritis Care Res (Hoboken) 2011;63:223230.

7. Pettersson $\mathrm{H}$, Nilsson IM, Hedner U, Noréhn $\mathrm{K}$, Ahlberg A. Radiologic evaluation of prophylaxis in severe haemophilia. Acta Paediatr Scand 1981;70:565-570

8. Foppen W, van der Schaaf IC, Fischer K. Value of routine ultrasound in detecting early joint changes in children with haemophilia using the 'Haemophilia Early Arthropathy Detection with UltraSound' protocol. Haemophilia 2016;22:121-125.

9. Martinoli C, Della Casa Alberighi O, Di Minno G, Graziano E, Molinari AC, Pasta G, Russo G, Santagostino E, Tagliaferri A, Tagliafico A, Morfini M. Development and definition of a simplified scanning procedure and scoring method for Haemophilia Early Arthropathy Detection with Ultrasound (HEAD-US). Thromb Haemost 2013;109:1170-1179.

10. Laucis NC, Hays RD, Bhattacharyya T. Scoring the SF-36 in orthopaedics: a brief guide. J Bone Joint Surg Am 2015;97:1628-1634.

11. Selivanova A, Buskens E, Krabbe PFM. Head-to-head comparison of EQ-5D$3 \mathrm{~L}$ and EQ-5D-5L health values. Pharmacoeconomics 2018;36:715-725.

12. Warren BB, Thornhill $D$, Stein J, Fadell M, Ingram JD, Funk $S$, Norton $K L$, Lane HD, Bennett CM, Dunn A, Recht M, Shapiro A, Manco-Johnson MJ. Young adult outcomes of childhood prophylaxis for severe hemophilia A: results of the Joint Outcome Continuation Study. Blood Adv 2020;4:2451-2459.

13. Geraghty S, Dunkley T, Harrington C, Lindvall K, Maahs J, Sek J. Practice patterns in haemophilia A therapy - global progress towards optimal care. Haemophilia 2006;12:75-81.

14. Blanchette VS. Prophylaxis in the haemophilia population. Haemophilia 2010;16(Suppl 5):181-188.

15. Manco-Johnson MJ, Lundin B, Funk S, Peterfy C, Raunig D, Werk $M$, Kempton CL, Reding MT, Goranov S, Gercheva L, Rusen L, Uscatescu V, Pierdominici M, Engelen S, Pocoski J, Walker D, Hong W. Effect of late prophylaxis in hemophilia on joint status: a randomized trial. J Thromb Haemost 2017;15:2115-2124.

16. Carroll L, Benson G, Lambert J, Benmedjahed K, Zak M, Lee XY. Real-world utilities and health-related quality-of-life data in hemophilia patients in France and the United Kingdom. Patient Prefer Adherence 2019;13:941957.

17. St-Louis J, Urajnik DJ, Ménard F, Cloutier S, Klaassen RJ, Ritchie B, Rivard GE, Warner M, Blanchette V, Young NL. Generic and disease-specific quality of life among youth and young men with Hemophilia in Canada. BMC Hematol 2016;16:13.

18. Soucie JM, Grosse SD, Siddiqi AE, Byams V, Thierry J, Zack MM, Shapiro A, Duncan N; Hemophilia Treatment Centers Network. The effects of joint disease, inhibitors and other complications on health-related quality of life among males with severe haemophilia A in the United States. Haemophilia 2017;23:287-293

19. Aledort $L$, Bullinger $M$, von Mackensen $S$, Wasserman J, Young NL, Globe $D$; Health Related Quality of Life Expert Working Group of the International Prophylaxis Study Group. Why should we care about quality of life in persons with haemophilia? Haemophilia 2012;18:154-157.

20. van den Berg HM, Feldman BM, Fischer K, Blanchette V, Poonnoose $P$, Srivastava A. Assessments of outcome in haemophilia - what is the added value of QoL tools? Haemophilia 2015;21:430-435.

21. Garcia-Dasi $M$, Aznar JA, Jiménez-Yuste $V$, Altisent $C$, Bonanad $S$, Mingot $E$, Lucía $F$, Giménez $F$, López MF, Marco $P$, Pérez R, Fernández MÁ, Paloma MJ, Galmes B, Herrero S, Garcia-Talavera JA. Adherence to prophylaxis and quality of life in children and adolescents with severe haemophilia A. Haemophilia 2015;21:458-464.

22. Khawaji M, Astermark J, Berntorp E. Lifelong prophylaxis in a large cohort of adult patients with severe haemophilia: a beneficial effect on orthopaedic outcome and quality of life. Eur J Haematol 2012;88:329-335.
23. Krishnan S, Vietri J, Furlan R, Duncan N. Adherence to prophylaxis is associated with better outcomes in moderate and severe haemophilia: results of a patient survey. Haemophilia 2015;21:64-70.

24. Fischer K, Poonnoose P, Dunn AL, Babyn P, Manco-Johnson MJ, David JA, van der Net J, Feldman B, Berger K, Carcao M, de Kleijn P, Silva M, Hilliard P, Doria A, Srivastava A, Blanchette V; Participants of the International Symposium on Outcome Measures in Hemophilic Arthropathy. Choosing outcome assessment tools in haemophilia care and research: a multidisciplinary perspective. Haemophilia 2017;23:11-24.

25. Melchiorre $D$, Linari $S$, Innocenti $M$, Biscoglio I, Toigo $M$, Cerinic MM, Morfini M. Ultrasound detects joint damage and bleeding in haemophilic arthropathy: a proposal of a score. Haemophilia 2011;17:112-117.

26. Muça-Perja M, Riva S, Grochowska B, Mangiafico L, Mago D, Gringeri A. Ultrasonography of haemophilic arthropathy. Haemophilia 2012;18:364368.

27. Ligocki CC, Abadeh A, Wang KC, Adams-Webber T, Blanchette VS, Doria AS. A systematic review of ultrasound imaging as a tool for evaluating haemophilic arthropathy in children and adults. Haemophilia 2017;23:598612.

28. Di Minno MND, Pasta G, Airaldi S, Zaottini F, Storino A, Cimino E, Martinoli C. Ultrasound for early detection of joint disease in patients with hemophilic arthropathy. J Clin Med 2017;6:77.

29. De la Corte-Rodriguez H, Rodriguez-Merchan EC, Jimenez-Yuste V. Pointof-care ultrasonography in orthopedic management of hemophilia: multiple uses of an effective tool. HSS J 2018;14:307-313.

30. Di Minno A, Spadarella G, Nardone A, Mormile M, Ventre I, Morfini M, Di Minno G. Attempting to remedy sub-optimal medication adherence in haemophilia: The rationale for repeated ultrasound visualisations of the patient's joint status. Blood Rev 2019;33:106-116.

31. Acharya SS, Rule B, McMillan 0, Humphries TJ. Point-of-care ultrasonography (POCUS) in hemophilia A: a commentary on current status and its potential role for improving prophylaxis management in severe hemophilia A. Ther Adv Hematol 2017;8:153-156.

32. Altisent C, Martorell M, Crespo A, Casas L, Torrents C, Parra R. Early prophylaxis in children with severe haemophilia $\mathrm{A}$ : clinical and ultrasound imaging outcomes. Haemophilia 2016;22:218-224.

33. Jiménez-Yuste $\mathrm{V}$, Álvarez-Román $\mathrm{MT}$, Martín-Salces $\mathrm{M}$, De la Corte-

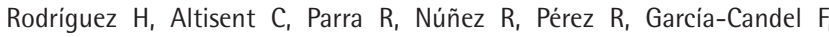
Bonanad S, Querol F, Alonso N, Fernández-Mosteirin N, López-Ansoar $E_{\text {, }}$ Garcia-Frade U, Bermejo N, Pérez-González N, Gutiérrez-Pimentel MJ, Martinoli C, Fernández-Arias I, Kim HK. Joint status in Spanish haemophilia B patients assessed using the Haemophilia Early Arthropathy Detection with Ultrasound (HEAD-US) score. Haemophilia 2019;25:144-153.

34. Li J, Liu W, Guo XJ, Ding XL, Lyu BM, Xiao J, Sun QL, Li DS, Zhang WF, Zhong JC, Li CP, Yang RC. HEAD-US-C quantitative ultrasound assessment scale in evaluation of joint damage in patients with moderate or severe hemophilia A received on-demand versus prophylaxis replacement therapy]. Zhonghua Xue Ye Xue Za Zhi 2018;39:817-821.

35. Banchev A, Stoyanova D, Konstantinov D, Ignatova I, Peteva E, Kaleva V, Kostova S, Petkova N, Dineva A, Pavlova A. Beyond the bleeding rates- HEAD-US joint assessment in patients treated by late prophylaxis. Haemophilia 2019;25:294-297.

36. Plut D, Kotnik BF, Zupan IP, Kljucevsek D, Vidmar G, Snoj Z, Martinoli C, Salapura V. Diagnostic accuracy of haemophilia early arthropathy detection with ultrasound (HEAD-US): a comparative magnetic resonance imaging (MRI) study. Radiol Oncol 2019;53:178-186.

37. Volland LM, Zhou JY, Barnes RFW, Kruse-Jarres R, Steiner B, Quon DV Bailey C, Hughes TH, Moore RE, Chang EY, von Drygalski A. Development and reliability of the joint tissue activity and damage examination for quantitation of structural abnormalities by musculoskeletal ultrasound in hemophilic joints. J Ultrasound Med 2019;38:1569-1581. 